\title{
PENGARUH SELAPANAN BANI MIDJO TERHADAP PENDIDIKAN KARAKTER KELUARGA
}

\author{
UNTAJI AFFAN \\ Universitas Muhammadiyah Magelang \\ e-mail: untajiaffan@gmail.com
}

\begin{abstract}
ABSTRAK
Ikatan persaudaraan dilandasi karena keturunan, agama atau keyakinan, wilayah, senasib, seprofesi. Ikatan keluarga yang didasarkan oleh nasab adalah lebih kuat. Namun dengan perkembangan zaman karena tuntutan pendidikan, pekerjaan, pernikahan kemudian keluarga menyebar ke wilayah yang berbeda. Hal ini pada akhirnya terjadi kerenggangan hubungan kekeluargaan. Untuk mengeratkan itu maka keturunan Bani Midjo mengadakan pertemuan secara rutin yang diselenggarakan setiap selapan hari. Pertemuan ini menjadi agenda rutin yang dikemas dalam kegiatan silaturahmi, pendidikan dan pengajian. Karena itu dengan pertemuan secara rutin ini mempunyai efek yang bagus, di mana antara keluarga bisa saling mengenal, dengan mengenal itulah maka kemudian tumbuh rasa saling menghormati, sehingga terwujud keakraban, kekerabatan dan kebersamaan.
\end{abstract}

Kata Kunci : Pengaruh Selapanan, Bani Midjo, Karakter Keluarga

\section{PENDAHULUAN}

Keluarga merupakan satuan terkecil dalam negara, keluarga akan menentukan baik buruknya suatu negara. Sebagai madrasatul ula dalam keluargalah cikal-bakal dasar-dasar pendidikan ditanamkan dan dilaksanakan (Peuradeun \& Journal, 2008) dalam berbagai macam tindakan keteladanan. Pendidikan informal dalam keluarga dilaksanakan, ayah dan ibu serta anggota keluarga yang lain sebagai pendidik berdasarkan pada usianya. Segala bentuk perilaku dan kebiasaan anggota keluarga akan diteladani terutama bagi anak-anak secara langsung. (Partono, 2020). Kompleksitas kehidupan masyarakat berawal dari keluarga, dalam kehidupan masyarakat setiap orang saling mempengaruhi. Sehingga masyarakat yang baik akan diawali dari keluarga yang baik, dengan landasan tata nilai, budaya, adat, agama dan kepercayaan.

Bangunan keluarga kecil terdiri dari ayah, ibu dan anak yang disebut sebagai keluarga inti. Setiap orang mempunyai tujuan yang berbeda-beda tentang jumlah anak. Sehingga keluarga kecil menjadi keluarga besar, karena disamping mempunyai anak lebih dari satu, di dalam keluarga juga terdapat orang tua, anak asuh, saudara dan asisten rumah tangga, dari keluarga inti bertambah terjadi penambahan dari keluarga lain yang hidup bersama dalam keluarga.(Peuradeun \& Journal, 2008)

Tumbuh kembang anak akhirnya menjadi orang yang dewasa, sampailah pada usia pernikahan, dengan pernikahan tersebut maka keluarga kemudian berkembang. Anak-anak menjadi remaja, remaja semakin dewasa, hingga menjadi orang tua dan yang tua terjadi regenerasi. Dengan perkembangan ini maka dengan alasan pendidikan, pekerjaan, perkawinan akhirnya menyebar dalam wilayah yang berbeda-beda. Karena itu sesama anggota keluarga akhirnya jarang berinteraksi yang bisa berakibat tidak saling mengenal. Kondisi tersebut menimbulkan keprihatinan dari kalangan orang-orang tua terhadap keberlangsungan kekeluargaan. Untuk itu diselenggarakan pertemuan keluarga yang diberi nama selapanan Bani Midjo.

Allah SWT telah menyampaikan bahwa asal-usul manusia itu adalah berasal dari satu orang, kemudian Allah memberikan jodoh. Dari perjodohan itu kemudian manusia berkembang biak "Wahai manusia, sesungguhnya Kami telah menciptakan kamu dari seorang laki-laki dan perempuan. Kemudian, Kami menjadikan kamu berbangsa-bangsa dan bersuku-suku agar kamu saling mengenal. Sesungguhnya yang paling mulia di antara kamu di sisi Allah adalah orang yang paling bertakwa. Sesungguhnya Allah Maha Mengetahui lagi Mahateliti (RI, 2009). Wahai manusia, bertakwalah kepada Tuhanmu yang telah menciptakanmu dari diri yang satu 
(Adam) dan Dia menciptakan darinya pasangannya (Hawa). Dari keduanya Allah memperkembangbiakkan laki-laki dan perempuan yang banyak. Bertakwalah kepada Allah yang dengan nama-Nya kamu saling meminta dan (peliharalah) hubungan kekeluargaan. Sesungguhnya Allah selalu menjaga dan mengawasimu. (RI, 2009)

Manusia adalah makhluk pribadi, sosial dan makhluk yang ber-Tuhan, tiga unsur melekat dalam diri manusia sehingga menjadi manusia yang sempurna. Selapanan Bani Midjo menjadi media untuk meraih ketiga-tiganya. Setiap pertemuan akan menyadarkan diri dari suatu yang sudah lupa atau belum diketahui dan dalam pertemuan akan dapat menerapkan pendidikan karakter. Pendidikan yang disampaikan oleh penceramah dan pembinaan yang disampaikan oleh orang tua. Implementasi kesalihan tercermin dalam sikap dan akhlaq baik terhadap orang yang lebih tua, kepada yang sebaya atau yang lebih muda.

\section{METODE PENELITIAN}

Penelitian ini merupakan penelitian diskriptif kualitatif yaitu dengan mencari dan mengumpulkan silsilah keluarga untuk selanjutnya melakukan pendataan tentang mutasi anggota keluarga, jadwal kegiatan, waktu pelaksanaan dan tingkat keaktifan bani. Bahwa tidak semua bani ikut berperan aktif dan berkontribusi, sehingga dari penelitian menghasilkan gambaran yang riil tentang pengaruh pertemuan dalam membentuk pribadi yang bekarakter.

Penelitian dengan cermat terhadap jejaring keluarga, jadwal kegiatan yang telah dibagikan namun dalam setiap minggu sebelum pelaksanaan, diingatkan melalui media whatsapp demikian pula pada setiap akhir acara disampaikan informasi dan pengumuman tentang tuan rumah pada pertemuan yang akan datang.

\section{HASIL DAN PEMBAHASAN}

\section{Hasil}

Bani Midjo adalah suatu paguyuban keluarga yang diselenggarakan setiap selapan hari sekali, paguyuban ini berawal keturunan Simbah Rejowikromo. Beliau mempunyai 6 anak yaitu 1)Ali Putri, 2)Arjo, 3)Kartorejo, 4)Muh Sobari, 5)Redjodikoro, 6)Kaswan. Dari keturunan pertama juga melahirkan putra-putra lagi 1)Ali Putri melahirkan i)Kamsori, ii)Masykur. 2)Arjo melahirkan i)Sarbini, ii)Darmo Pawiro, iii)Harjo Suwito, iv)Sumini. Dari 3)Kartorejo melahirkan i)W. Ismail, ii)Istiyah, iii)Edi Sukarsono, iv)Aminah, v)Basuki HS, vi)Istikomah, vii)Sri Kuntiati. Dari 4)Muh Sobari melahirkan i)Darindi, ii)Basiran al Hadi, iii)Rokhimah, iv)Ruslan, v)Siti Maryam, vi)Sugiyono, vii)Siti Romlah, viii)Idah, ix)Inap, x)Iswadi. Dari 5)Redjodikoro melahirkan i)Siswandi, ii)Paijem. Dari 6)Kaswan melahirkan i)Sidik Wasito, ii)Basirah, iii)Sodiyah.

Sesuai dengan Sunnatullah manusia diciptakan berpasangan, dari pasangan sehingga menjadi perjodohan dan berkembanglah menjadi banyak. Dari keturunan Simbah Redjowikromo ini sudah sampai pada keturunan kelima yang dalam budaya Jawa disebut Dimulai dari anak, cucu, buyut, canggah, wareng (https://www.google.co.id/books/edition/Sejarah_Sosial_Daerah_Istimewa_Yogyakart/).

Keturunan almarhum Simbah Kartorejo berkembang dan menyebar keluar dari desa Simbang misalnya ke Serang, Jlamprang, Ngadisari, Sigug. Ada yang tinggal di desa yang berbeda kecamatan, misalnya Baturan Sapuran, Kalierang Selomerto, Timbangg Leksono, Wonosobo, Kertek, Batakbanteng Kejajar, ada juga yang tinggal di desa yang berbeda kabupaten, misalnya di Magelang, Semarang, Pati, ada yang tinggal di desa yang berbeda provinsi, misalnya di Yogyakarta, Jakarta, Kalimantan. Bahkan ada yang tinggal di Melbourne Australia, tabel 1.

Tabel 1. Penyebaran Keturunan Bani Midjo

\begin{tabular}{|l|l|r|}
\hline No & \multicolumn{1}{|c|}{ Tempat Tinggal } & Jumlah \\
\hline 1 & Simbang Kalikajar & 78 \\
\hline 2 & Jlamprang Kalikajar & 7 \\
\hline 3 & Serang Kalikajar & 8 \\
\hline
\end{tabular}

\begin{tabular}{|l|l|r|}
\hline No & \multicolumn{1}{|c|}{ Tempat Tinggal } & Jumlah \\
\hline 11 & Timbang Leksono & 3 \\
\hline 12 & Pati & 3 \\
\hline 13 & Wonosobo & 3 \\
\hline
\end{tabular}


Vol 1. No. 4, Oktober 2021 P-ISSN : 2774-8030, e-ISSN : 2774-8030

\begin{tabular}{|l|l|r|}
\hline 4 & Segug Kalikajar & 3 \\
\hline 5 & Ngadisari Kalikajar & 15 \\
\hline 6 & Kertek & 3 \\
\hline 7 & Baturan Sapuran & 13 \\
\hline 8 & Kalierang Selomerto & 12 \\
\hline 9 & Patakbanteng Kejajar & 3 \\
\hline 10 & Patran Kalikajar & 8 \\
\hline & \multicolumn{2}{|c|}{} \\
\hline
\end{tabular}

\begin{tabular}{|r|l|r|}
\hline 14 & Magelang & 3 \\
\hline 15 & Semarang & 4 \\
\hline 16 & Yogyakarta & 1 \\
\hline 17 & Jakarta & 13 \\
\hline 18 & Kalimantan & 1 \\
\hline 19 & Australia & 4 \\
\hline & & \\
\hline & Jumlah & 185 \\
\hline
\end{tabular}

Untuk menjalin komunikas dhurriyah maka diselenggarakan pertemuan secara bergilir dari satu keluarga ke keluarga yang lain, tabel: 2. Pertemuan tersebut diselenggarakan setiap selapan (35 hari). (Nursam Windarti, 2016)

Tabel 2. Jadwal pertemuan Paguyuban keluarga bani kartaredja/ bani midjo Tahun 2016

\begin{tabular}{|c|c|c|c|c|c|}
\hline $\mathrm{NO}$ & NAMA & ALAMAT & $\mathrm{NO}$ & NAMA & ALAMAT \\
\hline 1 & $\begin{array}{l}\text { Titik Hermansyah } \\
\text { E }\end{array}$ & Serang & 21 & Iswadi Musrifah & Simbang \\
\hline 2 & Irop Agus & Jlamprang & 22 & Edi Sugeng & Simbang \\
\hline 3 & $\mathrm{Bu}$ Temo & Baturan Sapuran & 23 & Naprudin Imun & Simbang \\
\hline 4 & $\begin{array}{ll}\text { Joko } & \text { Nugroho } \\
\text { Wanti } & \\
\end{array}$ & Simbang & 24 & Suyanto Muji & Simbang \\
\hline 5 & Tutik Aidin & $\begin{array}{l}\text { Campusari } \\
\text { Kertek }\end{array}$ & 25 & Fatkhurrohman Sri & Simbang \\
\hline 6 & Tri Khotijah Bikis & Simbang & 26 & Aris Waryoto & Simbang \\
\hline 7 & Asiyah Ponijan & Simbang & 27 & Eni Sipon & Simbang \\
\hline 8 & Kodir Zuhriyah & Simbang & 28 & Sidik Wasito & Simbang \\
\hline 9 & H. Agus Erni & Yogyakarta & 29 & $\begin{array}{l}\text { Istikomah Amir } \\
\text { Usmanudin }\end{array}$ & $\begin{array}{l}\text { Kalierang } \\
\text { Selomerto }\end{array}$ \\
\hline 10 & Sunhaji & Simbang & 30 & Atun Dewan & Simbang \\
\hline 11 & Munadi Nunuk & Simbang & 31 & Aminah & Simbang \\
\hline 12 & Ambyah & Jlamprang & 32 & Umu Udin & Simbang \\
\hline 13 & Erna Darus & Simbang & 33 & Purwati Rasto & $\begin{array}{l}\text { Timbang } \\
\text { Leksono }\end{array}$ \\
\hline 14 & Resti Untaji Affan & Serang & 34 & Suyat Mukhodim & Simbang \\
\hline 15 & Takim Isti & Simbang & 35 & Basuki Siti Romlah & Simbang \\
\hline 16 & Siti Rahayu Santo & Simbang & 36 & Bambang & Simbang \\
\hline 17 & Ikhsan Suyadi & Simbang & 37 & Idah & Magelang \\
\hline 18 & Bu Basiroh & Simbang & 38 & Wahyu & Pati \\
\hline 19 & Rohmat Parti & $\begin{array}{l}\text { Kalierang } \\
\text { Selomerto }\end{array}$ & 39 & Rais Pratama Ermando & Semarang \\
\hline 20 & Siti Maryam Budi & Simbang & 40 & $\begin{array}{l}\text { Husen } \\
\text { Ermando }\end{array}$ & Kejajar \\
\hline
\end{tabular}

Kalikajar, 7 Agustus 2016

Selapanan adalah hitungan 35 hari selanjutnya diberi akhiran an yang bermakna adalah kegiatan yang dilaksanakan. Jumlah hari dihitung dari bertemunya hari- hari dalam seminggu yaitu Senin, Selasa, Rabu, Kamis, Jumat, Sabtu, Ahad bertemu dengan hari menurut pasaran 
yaitu Pon, Wage, Kliwon, Legi, Pahing yang disebut nepton (Alhogbi, 2017) . Jumlah hari dalam satu minggu berjumlah 7 , sedangkan hari menurut pasaran ada 5 hari.

Bani Midjo berasal dari 2 kata yaitu bani yang berarti anak, keturunan (anak cucu) (Poerwadarminta, 1976). Midjo adalah nama orang yang kepanjangannya adalah Kartorejo. Beliau lahir dan tinggal di desa Simbang Kecamatan Kalikajar Kabupaten Wonosobo. Sehingga Bani Midjo merupakan pertemuan keluarga, untuk mengeratkan ikatan kekeluargaan sebagai upaya untuk mengantisipasi pudarnya rasa persaudaraan.

Karakter berarti tabiat, watak, sifat-sifat kejiwaan, akhlak atau budi pekerti yang membedakan seseorang dengan yang lain (Poerwadarminta, 1976). Perilaku manusia yang dapat menjaga keseimbangan dan dapat menempatkan diri sebagai makhluk pribadi, sosial dan makhluk Tuhan, sehingga menjadi sikap dan perilaku yang santun dan menjunjung tradisi, budaya dan adat istiadat (Masrukhin, 2013). Kumpulan kekerabatan bisa menjadi media yang efektif untuk membentuk karakter dan perilaku religius (Rachman, 2016). Menurut Yusuf Qaradhawi: "pendidikan karakter merupakan pendidikan untuk menyiapkan mausia seutuhnya, manusia yang siap menghadapi segala macam kondisi kehidupan, baik dalam kondisi suka atau duka. Karena itu pendidikan karakter meliputi pendidikan jasmani, rohani, akal pikiran dan perilakunya (Izzani \& Rubini, 2021).

Pembahasan

Keprihatinan dari para orang tua adalah sangat masuk akal, dengan alasan 1) dari satu keturunan Bani Midjo yang semakin banyak, sehingga dari keturunan tersebut banyak yang tidak saling mengenal. 2) perkembangan ilmu pengetahuan semakin pesat, didukung dengan era digital banyak orang yang lebih mengutamakan media informasi seperti hand phone dari pada kegiatan sosial. Hal ini nampak bahwa suatu komunitas yang sedang berkumpul mereka disibukkan dengan media komunikasi seperti hand phone. 3)Era modernisasi, liberalisasi membuat orang semakin sibuk dengan urusannya sendiri, karena itu selapanan Bani Midjo menjadi media untuk mengeratkan silaturahmi.

Pertemuan Bani Midjo berbeda dengan pertemuan bani yang lain, dimana biasanya diselenggarakan 1 tahun sekali yang kebanyakan diselenggarakan dengan mengambil moment pada hari raya Idul Fitri. Adapun pertemuan Bani Midjo diselenggarakan setiap selapan hari yaitu setiap hari Ahad Wage. Dengan selapanan maka intensitasnya lebih cepat, sehingga pergantian pertemuan untuk menjadi tuan rumah akan lebih cepat. Pertemuan berdampak anggota keluarga bisa saling mengenal yang pada akhirnya terwujud keakraban. Keakraban ini terwujud ketika terjadi pembicaraan antara satu orang dengan yang lain tidak ada sekat-sekat yang menjadikan rasa sungkang, malu, rendah diri, tetapi masing-masing dapat menempatkan posisi dirinya dalam bersikap dan berperilaku. Yang tua menghargai pada yang muda, yang muda menghormati pada yang tua dan terhadap sesama anggota yang sebaya dengan kesamaan usia, cara pandang maka akan terwujud kenyamanan (Lia Purnamasari, 2008).

Intensitas pertemuan tersebut juga akan menciptakan keakraban dan persatuan hal ini nampak ketika salah satu anggota keluarga ada yang mendapatkan cobaan atau musibah maka keluarga akan saling membantu untuk meringankan penderitaan, baik dengan harta, pikiran dan tenaganya. Demikian pula bila ada keluarga yang sedang mendapatkan kebahagiaan maka keluarga yang lain akan turut merasakan bahagia dengan berpartisipasi aktif dalam kegiatan misalnya ketika ada sedang mempunyai hajat, seperti menikahkan, mengkhitani, mengadakan aqiqah dan lainnya.

Pertemuan Bani Midjo juga diikuti oleh suami atau istri dari Bani Midjo, sehingga disamping jumlah peserta yang hadir lebih banyak juga terwujud kebersamaan dalam keluarga inti yang akan berimplikasi pada keluarga besar. Memang dari semua keluarga Bani Midjo tidaklah bisa menghadiri hal ini karena kesibukan dan jarak yang jauh, disamping itu ada satu trah Bani Midjo yang tidak pernah mengikuti kegiatan tersebut yaitu trah Ali (putri). Hal ini berdampak pada terputusnya komunikasi yang berdampak pada hal-hal lain yang terkait.

Dalam pertemuan selapanan juga menjadi media pendidikan dan pelatihan, hal ini dilihat dari susunan acaranya 1) pembukaan, 2) pembacaan ayat-ayat suci Alquran, 3) 
pembacaan tahlil, 4) pembacaan kitab, 5) pengajian inti, 6) pembinaan, 7) penutup. Pada kegiatan pertemuan Bani Midjo dipimpin oleh MC atau pembawa acara. MC dilaksanakan secara bergantian, sehingga masing-masing bisa belajar, baik untuk bicara di depan umum, belajar untuk menjadi yang lebih baik, dengan indikasi tidak ada kata-kata yang salah, bahasanya runtut, kata-katanya mudah diterima dan dengan suara yang merdu. Sehingga dengan pengalaman tersebut, akan menjadi pribadi yang tidak mudah untuk menyalahkan orang lain, mencela atau menghina.

Pembacaan ayat suci Alquran juga dilakukan secara bergantian, baik dari kalangan anak-anak remaja atau orang dewasa. Sehingga ketika ada salah satu anggota keluarga yang bacaannya bagus, tidak ada kesalahan dalam mahraj, tajwid, irama dan lagunya yang indah, maka akan menjadi motivasi bagi keluarga yang lain untuk bisa menjadi lebih baik .

Acara yang ketiga adalah tahlil, hal ini menjadi media untuk mendoakan kepada para pendahulu yang telah meninggal. Tahlil adalah bacaan dzikir dan membaca ayat-ayat Allah. Di dalam Alquran Allah telah mengatakan bahwa perbanyaklah zikir (Kementerian Agama RI, 2012), karena dengan dzikir maka hati akan menjadi tenang (Kementerian Agama RI, 2012), maka dari pertemuan Bani Midjo setiap anggota dilatih untuk selalu memperbanyak dzikir. Di dalam tahlil juga ada rangkaian membaca ayat-ayat suci Alquran. Alquran bisa menjadi obat dan rahmat (Kementerian Agama RI, 2012) bila dibaca atau didengarkan maka orang yang membaca akan menjadi tenang. Dengan membaca Alquran akan mendapatkan pahala, karena Allah akan melipatgandakan pahala yang dihitung dari jumlah huruf yang dibaca. Pahala akan berdampak pada jalan untuk meraih cita-cita, karena pahala yang banyak akan menjadi wasilah dalam berdoa.

Acara yang keempat adalah pembacaan kitab, hal ini menjadi media pendidikan. Pembacaan kitab dapat menumbuhkan kesadaran pada orang tua untuk memberikan pendidikan agama kepada anak-anak dengan melanjutkan pendidikan, baik di sekolah atau di pondok pesantren. Pembacaan kitab yaitu dari kitab klasik karya ulama terdahulu yang diperoleh dari pendidikan, khususnya di pondok pesantren. Pembacaan kitab juga memberikan pengetahuan atau mengingatkan tentang dasar-dasar pendidikan Islam. Dari pembacaan kitab tersebut keluarga akan mengetahui kaifiyah dalam beribadah, misalnya tata cara berwudhu, cara memilih air, cara melaksanakan shalat, puasa dan hal-hal lainnya.

Acara yang kelima adalah pengajian atau tausiah yang disampaikan oleh kyai atau ustadz tergantung pada kemauan tuan rumah. Tausiyah ini untuk memberikan bekal ilmu pengetahuan, ibadah dan amaliah yang bersifat umum. Biasanya topiknya yang berkaitan dengan peristiwa pada saat itu, sehingga anggota mempunyai landasan dan pedoman dalam menghadapi tantangan kekinian.

Acara keenam adalah pembinaan acara ini disampaikan oleh sesepuh atau tokoh sentral Bani Midjo. Pembina berupaya untuk merangkul semua anggota, memberikan motivasi dan perlindungan. Karena itu pembinaan ini lebih banyak menyampaikan tentang pesan-pesan dan pentingnya menjalin shilaturahmi. Dan pentingnya untuk bersikap sederhana terutama ketika memberikan hidangan.

Setelah acara selesai untuk ibu-ibu dan kelompok wanita melanjutkan kegiatan yang lain yaitu arisan, hal ini menjadi di media untuk mengikat antara sesama anggota, karena ketika ikut dalam kegiatan arisan tentu setiap orang mempunyai rasa ketergantungan. Satu sisi ingin mendapatkan undian untuk memperoleh dana arisan, yang kedua adalah rasa tanggung jawab untuk membayar arisan. Sehingga dengan arisan ini menjadi motivasi bagi anggota, keluarga untuk hadir dalam kegiatan pertemuan selapanan Bani Midjo.

Perkumpulan keluarga Bani Midjo menjadi organisasi keluarga yang diikat karena hubungan darah dari satu generasi ke generasi. Organisasi ini berkembang dengan bentuk yang berbeda, dari waktu, kegiatan dan instensitas pertemuan (Partono, 2020). Kemudian layaknya suatu organisasi, Bani Midjo juga mempunyai struktur kepengurusan yaitu ketua sekretaris dan bendahara. Tujuannya adalah untuk mengkoordinir anggota agar selalu bisa menepati kehadiran dalam pertemuan. Dalam kepengurusan setiap keluarga dimintai dana untuk memberikan 
bantuan bagi keluarga yang mendapat giliran ketika menjadi tuan rumah. Disamping itu bahwa dana kas itu juga digunakan untuk memberikan bantuan transportasi kepada anggota bila pertemuannya berada di luar desa Simbang, karena itu tidak menjadikan kesulitan bagi keluarga untuk bisa menghadiri pertemuan tersebut.

Pertemuan keluarga Bani Midjo berbeda dengan keluarga bani yang lain, karena di dalam pertemuan pelaksanaannya adalah setiap 35 hari sekali. Dengan intensitas pertemuan tersebut maka diantara keluarga Bani Midjo selalu bisa meluangkan waktu untuk menghadiri acara tersebut, bahkan menjelang pelaksanakan dengan melalui sms atau wa saling mengingatkan. Dengan demikian terwujud suasana saling mengenal, yang selanjutnya semakin kuat rasa kebersamaan dan kekeluargaannya. Keluarga Bani Midjo mempunyai ikatan emosional yang kuat, sehingga ketika ada salah satu anggota yang sedang mendapatkan musibah, maka secara bersama-sama akan menghibur dan memberikan pertolongan sesuai dengan kadar kemampuan masing-masing, bisa dengan tenaga, pikiran, harta atau doanya.

Karakter Bani Midjo selaras dengan dengan firman Allah yaitu untuk bertolongmenolong dalam kebaikan dan taqwa dan jangan bertolong menolong dalam dalam melakukan perbuatan keji dan munkar, (Kementerian Agama RI, 2012), saling memberikan pesan dalam melakukan perbuatan yang baik dan berbuat sabar. (Kementerian Agama RI, 2012). Menurut Syamsu Yusuf, bahwa keluarga menjadi salah satu komponen dalam pembentukan kepribadian anak (Partono, 2020).

Dengan pertemuan rutin tersebut, maka keluarga benar-benar merasakan enaknya menjadi keluarga, banyak kejadian bahwa keluarga namun seperti orang lain, karena tidak saling mengenal. Hal ini karena jarang bertemu antara satu orang dengan yang lain, berbeda dengan keluarga Bani Midjo walaupun masing-masing sudah mempunyai pekerjaan, profesi yang berbeda, masing-masing juga mempunyai kesibukan dan tinggal dalam wiilayah yang berbeda-beda tetapi dengan komitmen untuk mengukuhkan rasa persaudaraan maka pertemuan keluarga Bani Midjo selalu bisa terlaksana. Kecuali pada masa pandemi Covid-19, hampir selama 2 tahun tidak menyelenggarakan pertemuan. Walaupun demikian tetapi antara keluarga terjalin ukhuwah dengan media sosial, grup wa dan lainnya.

Sepanjang perjalanan pertemuan Bani Midjo belum dihadiri semua bani, dari 6 orang generasi pertama namun yang aktif dalam pertemuan keluarga hanya 5 keturunan. Sehingga dari 5 bani, keturunan pertama bisa saling mengenal, dan terwujud rasa persaudaran, persatuan, kesatuan dan kekrabatan. Berbeda dengan satu orang dari keturunan pertama. Tentunya tidak saling mengenal, sehingga sekalipun masih keluarga namun menjadi seperti orang lain.

Sifat kebersamaan, kerukunan, persatuan yang sudah dilaksanakan, ternyata menimbulkan rasa kagum pada keluarga yang lain. Hal ini nampak jelas bila salah satu anggota sedang sakit semuanya saling berkomunikasi dan mengunjungi secara bersama-sama, demikian pula bila ada kerabat dari Bani Midjo yang meninggal dunia. Kekaguman dari masyarakat tersebut selanjutnya menimbulkan iri, mengapa keadaan seperti itu tidak terwujud di baninya.

Karena pertemuan Bani Midjo berpengaruh pada pendidikan karakter, Thomas Lickona yang menyebutkan tentang pendidikan karakter meliputi; 1) Ketulusan hati atau kejujuran (honesty); 2) Belas kasihan (compassion); 3) Kegagahberanian (courage); 4) Kasih sayang (kindness); 5) Kontrol diri (self-control); 6) Kerja sama (cooperation); 7) Kerja keras (hard work) (Izzani \& Rubini, 2021). Dengan pelaksanaan yang secara rutin sifat-sifat tersebut menjadi karakter keluarga yang dengan aktif mengikuti pertemuan Bani Midjo.

\section{KESIMPULAN}

Manusia diciptakan oleh Allah berpasang-pasangan, sehingga manusia berkembang, dari satu keturunan berkembang menjadi banyak. Ketika masih sedikit dan tinggal dalam satu wilayah maka akan mudah terjalin komunikasi, saling membantu dan menolong. Namun suatu waktu manusia berkembang menjadi banyak dan menyebar ke seluruh wilayah, sehingga walaupun merupakan keluarga menjadi jarang bertemu, tidak pernah komunikasi dan tidak 
mengetahui kondisinya. Karena itu untuk mengakrabkan keluarga diselenggarakan pertemuan selapanan Bani Midjo.

Selapanan keluarga dapat mewujudkan sikap saling menghormati, menghargai, tolong menolong, pengendalian diri, mewujudkan kekerabatan, kebersamaan dan persaudaraan. Belajar dari orang lain dalam bertutur kata, bersikap dan pembinaan keluarga sakinah. Karena itu pertemuan Bani Midjo selama selapan hari menjadi waktu yang ideal, tidak terlalu lama dan tidak terlalu cepat. Karena itu pada anggota akan mempunyai kesiapan untuk menghadiri, terkecuali ada hal-hal mendesak yang tidak bisa dihindari.

\section{DAFTAR PUSTAKA}

Alhogbi, B. G. (2017). Makna Tradisi Selapanan Pada Masyarakat Jawa Di Desa Gedung Agung. Journal of Chemical Information and Modeling, 53(9), 21-25. http://www.elsevier.com/locate/scp

Izzani, R., \& Rubini, R. (2021). Pendidikan Karakter dalam Buku Sirah Nabawiyah Karya Syaikh Shafiyyurrahman al-Mubarakfuri. Al-Manar, 10(1), 103-114. https://doi.org/10.36668/jal.v10i1.256

Kementerian Agama RI. (2012b). Al Qur'an dan Terjemahnya. PT Sinergi Pustaka Indonesia.

Lia Purnamasari, A. S. (2008). Pengaruh Pergaulan Teman Sebaya dan Lingkungan Keluarga Terhadap Minat Ekstrakurikuler di Kalangan Siswa. 6-7.

Masrukhin, A. (2013). Model Pembelajaran Character Building dan Implikasinya Terhadap $\begin{array}{llll}\text { Perilaku Mahasiswa. } & \text { Humaniora, }\end{array}$ https://doi.org/10.21512/humaniora.v4i2.3566

Nursam Windarti, S. S. (2016). Kamus Bahasa Jawa (I). PT Buku Seru.

Partono. (2020). Pendidikan Akhlak Remaja Keluarga Muslim di Era Industri 4.0. Dirasah: Jurnal Studi Ilmu Dan Manajemen Pendidikan Islam, 3(1), 71-84. https://doi.org/10.29062/dirasah.v3i1.78

Peuradeun, J. I., \& Journal, I. M. (2008). PENDIDIKAN DALAM KELUARGA Basidin Mizal 1. Jurnal Pendidikan Keluarga, II Tahun I, 155-178.

Poerwadarminta, W. J. S. (1976). Kamus Umum Bahasa Indonesia (V). PN Balai Pustaka.

Rachman, F. (2016). KOMPOLAN KEKERABATAN / BANI: LABORATORIUM PENDIDIKAN KARAKTER DAN BUDAYA RELIGIUS. 1(1), 1-38.

RI, D. A. (2009). Al Qur'an dan Tafsirnya (Kedua). Pustaka Nasional RI: Katalog Dalam Terbitan (KDT). 